American Journal of Economics and Business Administration 1 (4): 303-312, 2009

ISSN 1945-5488

(C) 2009 Science Publications

\title{
Sui Generis Plant Variety Protection: The Indian Perspective
}

\author{
${ }^{1}$ Rohan Dang and ${ }^{2}$ Chandni Goel \\ ${ }^{1}$ Symbiosis Law School, Pune, India \\ ${ }^{2}$ NALSAR University of Law, Hyderabad, India
}

\begin{abstract}
Problem statement: Plant variety protection relates to intellectual property rights over plant varieties which guarantee rights-holders exclusive commercial rights for a specific period of time. Article 27 (3)(b) of the TRIPS Agreement, compulsorily mandates that every member-state of the WTO must introduce such protection through domestic legislation by certain set time frames. These rights are one form of IPR being aggressively imposed on developing countries and are often touted as a 'soft' patent regime. Plant variety laws are just as threatening as industrial patents on biodiversity and also represent an attack on the rights of farming an other communities at the local level. From a legal perspective, the protection of plant varieties in India remains an issue which is far from settled even though the Protection of Plant Varieties and Farmers' Rights Act was adopted in 2001 in compliance with the TRIPS Agreement. This study argued that the goal of the IP regime should be to balance the competing needs of maximizing societal innovation while appropriately rewarding the individuals that contribute to that innovation. Towards this end, the study seeks to analyze the issues related to the protection of plant varieties with reference to the TRIPS agreement along with the biodiversity treaty and the PGRFA Treaty. One of the chief distinguishing features of the PGRFA Treaty is its emphasis on farmers' rights. This characteristic is analyzed further in the Indian context. Conclusion: Plant variety protection is linked to both agricultural innovation and the conservation of biological resources, although on different levels. The present international legal framework remains partly inconclusive with regard to they type of agricultural management that it seeks to encourage. Though the development of sui generis programs for plant variety protection is still in a nascent stage, this paper analyses the advantages and disadvantages of the Farmers' Rights Act, 2001 and submits proposals for a better future. In conclusion, IPR and agriculture and sustainable development are indeed integrated and the homogenization of international law is the only panacea to the mutual needs of both, the North and the South.
\end{abstract}

Key words: Plant variety protection, developing nations, sui generis, farmer's rights

\section{INTRODUCTION}

Agriculture is one of the most interesting fields to analyze in the context of intellectual property rights because there have been significant law and policy changes in the past few decades in this area. While local, national and international efforts to increase food security were traditionally often undertaken on the basis that the relevant knowledge should be in the public domain (Principle of the "Common Heritage of Mankind".), the situation has significantly changed and is still rapidly changing in developing countries.

In the early part of the twentieth century, in the United States and European countries, agriculture became less important economically and governments started to progressively reduce their involvement in activities related to the development and supply of seeds to farmers. This led to the development of more significant private sector seed industries. However, its expansion was curtailed by the nature of seeds which can, once purchased, often be reused for several generations by farmers ${ }^{[1]}$. This led to the call for a legal protection of plant varieties. There were several obstacles to the introduction of patents for plant varieties, firstly, from actors opposed in principle to the introduction of patents on life forms. Secondly, there was opposition to what was perceived as the progressive privatization of seeds which had been traditionally exchanged by farmers ${ }^{[2]}$. Thirdly, there was significant opposition from advocates of the patent system who saw a new 'plant variety' as more like an improvement of an existing product of nature than as a scientific invention ${ }^{[3]}$. The combination of the push led to the development of a hybrid form of intellectual property rights known as 
'plant breeder's rights' (Hereinafter referred to as PBRs) which received recognition in 1961 in the UPOV convention, revised first in 1978 and strengthened later in 1991.

In the TRIPS era, the situation has significantly changed since introducing plant breeders rights is recognized as 'one' of the ways to satisfy the TRIPS agreement $^{[4]}$ concerning 'plant variety protection' (Hereinafter referred to as PVPs). While commercial plant breeding was increasingly benefiting from protection offered by PBRs or patents, there was no system of compensation or incentives for farming communities $^{[5]}$ who had a fundamental role in maintaining sustainable agricultural practices, conserving plant genetic resources and enhancing agrobiodiversity through their innovations. This equitable sharing of benefits was the basic premise for the development of 'farmer's rights' which first found recognition in 1989 in the international undertaking on plant genetic resources and finally in the PGRFA treaty in 2001. This struggle for a fine balance between breeder's rights and farmer's rights is where the present study finds relevance within the 'sustainability' debate between trade and environment.

The introduction of IPR in agriculture is an important question because it directly touches upon questions of economic development, agricultural management, environmental management and the fulfillment of the basic right to food. Significant attention needs to be given to the development of a legal framework that takes into account all these dimensions together. Endeavors towards the same, along with a balanced critique of the existing legal regime- both national and international, form the main objectives of the research undertaken.

Potential advantages of PVPs for developing nations: The introduction of PVPs was meant to reduce one of the barriers to international trade in agriculture by opening up the developing country markets to hybrids which have the ca9acity to reduce traditional deficiencies in agriculture ${ }^{[6]}$. Like all other forms of IPRs, plant variety protection enhances foreign investment as foreign breeders are encouraged to invest in countries that provide adequate safeguards for their high risk investments ${ }^{[7]}$. The legal protection offered by intellectual property rights is one of the most important incentives for private sector involvement in agrogenetic engineering. IPRs are thus primordial in ensuring the participation of the private sector in the development of new plant varieties.

Improvements that can be brought about by agrogenetic engineering include plant varieties that produce higher yields by enhancing the capacity of the plant to absorb more photosynthetic energy into grain rather than the stem or leaf; varieties that have the capacity to combat pests and adverse weather conditions and varieties modified to grow faster through enhanced efficiency in the use of inputs such as fertilizers, pesticides and water ${ }^{[8]}$. Viewed in the context of the developing world's food security concerns, the only solution for the loss of land under cultivation owing to mounting urbanization and industrialization, is to increase the 'productivity per unit area'. From this 'food security' point of view another potential feature is the possibility to modify varieties to improve their nutritional value. Thus, between maintaining the status quo and introducing PVPs, the latter may foster food security in developing countries provided the risks are appropriately allocated ${ }^{[9]}$.

Impact of PVPs on developing nations: Developing nations underscore several factors necessitating a national regime for plant variety protection rather than adopting a system similar to the protection prevalent in developed nations. First, in developing nations agriculture has a close nexus to the national economy. Compared to developed nations, the agricultural population is higher in developing nations. The economic dependence differentiates the agricultural sectors of the south from that of the north. The differences include smaller land holdings and labour intensive agricultural practices, subsistence land farming and lower participation in international trade. These distinguishing features of agriculture and its impact on their economies, developing nations opine, necessitates prioritization of national goals when introducing PBRs (to take an example, the percentage of people engaged $n$ the agricultural sector in the European Union in 1961 was only 20 percent when the UPOV Convention was adopted).

In furtherance to this, the main concern of most developing nations is the scepticism attached to the process of privatization, which suo moto brings with itself multifarious socio-economic and environmental concerns. Some of the particular concerns are:

- Private sector investment results in consumeroriented food instead of catering to the needs of the poor: The first generation of GM crops have generally not been bred for raising yield potential and any gains in yield and production have come primarily from reduced losses to pests. This indicates that introduction of IPR in developing countries should be accompanied by further measures to ensure that research is also geared 
towards the needs of the poor. One way to do the same would be through public-private partnerships where the private variety is adapted by the public sector to subsistence farming ${ }^{[10]}$

- Restriction on traditional practices and harmful effects of terminator technology: Most PVP practices restrict the farmer's traditional practice of saving harvested crop for subsequent sowing. Technologies such as Genetic Use Restriction Technology (GURT) render the harvested crop sterile for further cultivation. In the context of developing countries, this is disastrous as this practice of saving the harvested crop is essential towards the survival of the farmer and towards the alleviation of poverty. The cost of cultivation due to high input cost contains the potential to be devastating, if PVP were to be used and the harvest was to fail

- PVPs themselves have not necessarily fostered food security: Although the trade liberalization concerning agriculture envisages alleviating the economic situation of the farms and patterns of food consumption, but in reality the situation shows a declining pattern. The process of globalization of agriculture has undermined the food security goals that the states aim to attain ${ }^{[1]}$ and there is no clear indication that with the introduction of PVP that food security has increased $^{[12]}$. Further, having to pay substantial royalties to industrial countries and corporations could greatly increase the debt burdens of many countries. This could further intensify the environmental and social disruption that is caused when debt repayment measures are taken up, such as the export of natural products

- Effects on biodiversity: Agriculture and biodiversity management are inextricably intertwined because biological resources constitute a primary input to agricultural production systems and the majority of existing agricultural products have evolved through selection and collection of plant and animal. Intellectual property rights in agriculture have an inherent tendency to displace landraces because protected varieties generally offer higher yields than the local counterparts. This tends to promote homogenization which leads to a loss in diversity and generally reduces crop's resilience to pests and diseases ${ }^{[10]}$ Thus in terms of the environment, the breeding uniformity results in monocultures after a stage, which are ecologically unstable

- Over patentability: The genetic engineering industry may have the potential to stifle innovation in the private and public sector rather than promote $\mathrm{it}^{[13]}$ The perception is often that broad clams are necessary to provide the industry with sufficient incentives to innovate but that intellectual property rights claims should not extend to the primary material for research because this tends to stifle scientific and technological innovation

- Miscellaneous: It has also been claimed that new plant varieties have the tendency to raise potential epidemic zones as they are prone to diseases. This is because they are vulnerable to the externalities, having been developed in ideal lab conditions. Further, wild strains or weeds are not preserved in the alternative of new plant varieties, which themselves form essential raw materials for new technologies like genetic engineering research

Thus, the overriding impacts of PVPs can be put in perspective in the weighty words of Kuyek ${ }^{[14]}$.

"Patent proponents keep banging on about the importance of IPR for access and innovation. But this is a smokescreen. If access was the issue, then the evidence stands against IPR; it restricts the flow of germplasm, reduces sharing between breeders, erodes genetic diversity and all in all, stifles research. What is actually at the issue is the question of whose interests' agriculture R and D should serve. IPRs are suited to the profit strategies of the global seed conglomerates that want to dominate agricultural production worldwide. The transnational seed companies are building vast industrial breeding networks in all major crops and with their economies of scale and ownership they will shut local private and public breeders out of the commercial market. For them, IPR is simply a means for controlling the market and extracting more profit from it ${ }^{[14]}$,.

International legal regime for PVPs: An overview: The TRIPS agreement ${ }^{[15]}$ was established as a part of the WTO regime that came into operation on January 1, 1995. The TRIPS agreement lays down certain minimum standards for intellectual property rights that the contracting parties of the WTO had to implement through their own national legislations. These minimum standards have caused a significant shift in the IPR regime, away from the public interest and towards the monopolistic privileges of IPR holders. TRIPS is a legally binding international instrument enforceable in the WTO, across all 140 members. This gives rise to 
great inequity between the developed and developing states, as TRIPS has effectively globalized a 'one-sizefits-all' system of IPRs where the same standards are set for countries of differing levels of development. Unfortunately, it is in the developing countries where the effects of many of its provisions are felt.

In areas that are comparatively of more importance to the developing countries, such as farmer's rights and the protection of traditional knowledge, the international legal framework remains dramatically underdeveloped. As a result, developing countries have the twin burden of adapting themselves to their existing international obligations and to adopt legal frameworks in areas that matter to them even if international law is not developed concerning these issues. Before TRIPS, many developing countries did not permit the patenting or intellectual protection of life forms, biological resources and traditional knowledge. This changed completely with Article 27(3) (b) which specifically mentions the protection of plant varieties through either a patent regime or a sui generis system, or a combination of the two, within a time barred frame till 1st January, 2000. The plant breeders rights regime introduced by the UPOV Conventions (discussed at length later) served as the only fall back option for many developing countries that did not have the time or resources to develop their own locally relevant sui generis systems.

Plant variety protection under TRIPS has come in conflict with a large number of other international instruments which most countries are a party to. An important one amongst the same is the Convention on Biodiversity (CBD). Article 1 of the CBD states its objectives as- "the conservation of biological diversity; the sustainable use of its components and the fair and equitable sharing of the benefits arising out of the use of genetic resources". The consequences of the TRIPS agreement are inconsistent with the objectives put forth by the CBD as biotechnology supported through PVPs tends to breed uniformity which eventually destructs genetic diversity. A culture of monopolisation of independent innovations is incoherent with sustainable development and equitable sharing of benefits is difficult if not impossible with the increasing grant of IPRs on primary genetic resources as well.

With respect to the debate on asymmetric benefits, The International Undertaking ${ }^{[16]}$ provided the lineaments of an international concept of 'farmer's rights' but stopped at general considerations. At present the PGRFA Treaty ${ }^{[17]}$ provides the only existing recognition of farmer's rights in a binding instrument. It does not however, provide a substantive definition of farmer's rights and in particular, it does not provide any form of 'property rights' for farmers over their knowledge, similar to those that plant breeders claim over their innovation. As a result, farmer's rights at the international level are currently little more than a policy tool to foster the recognition of the contribution of farmers and farming communities in the overall conservation and development of plant genetic resources. International law with respect to farmer's rights is fragmented if not incoherent. It is however submitted that the fact the farmer's rights have not been fleshed out internationally, can indirectly prove positive for developing countries (through the sui generis option) who need to implement the different commitments they have taken at the international level harmoniously, while keeping in mind their constitutional obligations and policy needs ${ }^{[9]}$.

Sui generis plant variety protection: An assessment: The question of sui generis intellectual property right protection for plant varieties has become a matter of great importance following the adoption of TRIPS. Article 27(3) b specifically requires all member states to "provide for the protection of plant varieties either by patents or by an effective sui generis system or by a combination thereof'. This in essence sheds light on two broad aspects Firstly, a number of countries in the North and the South rejected the compulsory introduction of plant patents. Secondly, negotiators did not manage to agree on one specific alternative to patents. As a result, TRIPS gives member states a wide margin of appreciation in determining how to implement their TRIPS obligations in keeping with their Constitutional goals and other international commitments.

Importance of a sui generis system: Firstly, the sui generis system presents the possibility of an additional option of choosing 'new forms of intellectual property rights' which are not necessarily based on the existing ones such as patents or plant breeder's rights. Secondly, the idea of sui generis protection provides developing countries with the 'conceptual justification' to look beyond established categories of IPRs and protect certain categories of inventions in accordance with the specificities of the field concerned and the distinct needs of individual countries. Thirdly, it provides a foundation for integrating intellectual property rights and sustainable development.

Constituents of an 'effective' sui generis system: The prominence of the UPOV convention ${ }^{[18]}$ in the debates concerning sui generis PVPs is in part linked to the fact that the interpretation of the concept of 'effective' sui 
generis system in Article 27(3)b remains problematic. Under one school of thought 'effectiveness' can be linked to 'enforcement', that is, the narrow concerns of the intellectual property rights holders and their interest in having any rights recognized and enforced under Part III of the TRIPS Agreement. 'Effectiveness' on the other hand can be read as the introduction of a protection regime which comprehensively protects 'all actors' involved in plant variety conservation and development, that is- commercial actors and other actors involved in agriculture. A number of states that have not had the time or resources to develop a completely separate and locally relevant sui generis regime, have decided to take plant breeder's rights under the UPOV without full consideration of its impacts (member states of the African Intellectual Property Organization simple adopted a regime modeled after the 1991 Act of the UPOV Convention and at the same time committed themselves to joining the UPOV Convention on 24th February 1999 in the "Bangui Agreement").

Some important constituents of an 'effective' sui generis system involve- Firstly, a sui generic protection system should not stop at protecting the interests of the innovators alone, but should also seek to provide a framework which specifically promotes "food security" in coherence with Article 8 of the TRIPS Agreement. Secondly, an effective sui generis system is that which integrates sustainable development with intellectual property rights regime in accordance with Article 7 of TRIPS.

UPOV does not constitute an effective sui generis system: The introduction of PVP as a consequence of adoption of the TRIPS agreement is one that concerns mostly developing countries as most developed countries has introduced either patents or PBRs before the adoption of the TRIPS agreement. The UPOV convention gains prominence here due to the interpretation of concept of 'effective' sui generis system as per Article 27(3) (b) of the TRIPS agreement. The only generally agreed interpretation is that UPOV is an effective sui generis protection regime under TRIPS $^{[9]}$. Consequently, a number of states have taken the UPOV convention as the model for a plant variety protection regime. However, the very effectiveness of the UPOV system is in question.

UPOV is deficient in accommodating national goals, as it does not balance the interests of breeders with other interests vital to developing nations, such as those of farmers. UPOV has several deficiencies and the same have been highlighted below. UPOV preserves very small improvements as breeders' rights and grants rights that are disproportionate to the creativity in plant breeding. The rights that UPOV gives rise to, allow for a breeder to appropriate from the public domain, thus harming the genetic diversity. This must be seen in light of developing nations, where genetic diversity is viewed as an integral part of their social and economic structure. The UPOV Convention also gives rise to:

- Diluted standards for protection

- Breeders' rights are disproportionate; the scope is too wide

- Inadequate restrictions of breeders' rights

The UPOV Convention dilutes standards for the protection of varieties. There are loopholes present that skew UPOV towards breeders, against of farmers' rights and show its inability to appropriately identify creativity in plant breeding. UPOV vests protection on varieties that are 'new, distinct, uniform and stable'

Article 6, UPOV Convention, deems a variety as 'new', solely by whether it has been sold prior to the date of filing of the application for protection of the plant variety, or disposal by the applicant or with the consent of the same for the purpose of exploitation of the plant variety. Public knowledge is not a bar as to determine whether a variety is new or not. Plants that are already known may still become eligible for protection as a new variety.

The only feature required for a plant variety to appear as distinctive is the ability to be distinguished from another variety that is essentially whether such variety has been entered in the official register or for which an application has been made prior to the filing of the current application. Here as well, common or public knowledge of the variety is not a bar for making an application for protection under UPOV. The distinctiveness requirement under UPOV is a highly diluted version of the novelty and non-obviousness requirements of the utility patent system ${ }^{[6]}$.

The scope of breeders' rights as envisaged by UPOV, is much too wide. Breeders' rights extend to the protected variety and 'varieties not clearly distinguishable' from the protected variety (UPOV 1991) through Article 14(5) (a). However, Article 14(5) (b) extends protection to essentially derived varieties, which are clearly distinguishable varieties derived from the initial variety. Thus, breeders' rights extend to indistinguishable as well as distinguishable varieties derived from the initial variety. Therefore a breeder can claim rights of other farmers or breeders' experimental varieties, even if such varieties are clearly distinguishable from the protected variety. It must be 
noted that Article 15 does give rise to exceptions to breeders' rights. The compulsory exceptions include acts done for private, non-commercial and experimental purposes. Breeders can override even these compulsory exceptions by conditioning initial access to the protected variety on forfeiture of these rights. This broad scope of PBRs in UPOV has resulted in a narrow scope of farmers' rights.

UPOV treats farmers' rights as negotiated exemptions of breeders' rights ${ }^{[19]}$. This shows that UPOV is unable to balance breeders' rights with farmers' rights and this inequity gives rise to welfare issues in developing countries where there is a higher population of small farmers as compared to developed countries. The only UPOV restriction on breeders' rights exists under the 'public exception' clause of Article 17 of UPOV 1991. This term is undefined and UPOV does not indicate what the term is and who determines when public interest is affected.

Therefore, the UPOV Convention cannot be called an 'effective sui generis' system and it should clearly not act as a model legislation for developing countries which must adopt a sui generis system or a modified patent regime for the protection of plant varieties in consequence of Article 27(3)(b) of the TRIPS Agreement.

Flexibility under the TRIPS agreement: Plant variety protection in the South is a creation of the TRIPS Agreement. Being the primary document framed with the purpose of harmonizing domestic laws of member countries with respect to intellectual property, it mandates certain minimum requirements ${ }^{[20]}$ that each contracting party to the WTO must conform with. Along with providing for strict obligations, the TRIPS agreement also affords certain exceptions and flexibilities. Article 27(3) (b) states that member states have to provide protection for plant varieties by patents or by sui generis systems or a combination of both. The option or exception of a sui generis system was generated as a viable alternative to the patent system for plant varieties as it provides sufficient flexibility to developing countries to design a system that best fits their circumstances and meets their goals and objectives $^{[21]}$.

Developing countries which are WTO members have multiple concerns; firstly they must implement all their international obligations in a coherent manner at the national level and secondly, the TRIPS agreement is one set of international obligations which must run concurrently with several others, especially in the context of food security related intellectual property rights. Thus, the flexibility that the TRIPS agreement contains relating to the sui generis system of PVP is of immense importance and advantage to developing countries as a viable option is present, as opposed to the application of a patent regime for PVPs.

Therefore, it is for developing countries to make the most of the inbuilt flexibility and India has responded to the TRIPS requirements by enacting a sui generis legislation that aims to provide protection for plant varieties, rights to the farmers and breeders and incentives for the development of new varieties of plants.

Sui generis PVPs in India: India play's a very critical role in the plant variety protection debate, representative of the vulnerabilities and ambitions of the developing nations. This owes itself to the following reasons:

- India is a germplasm-owning country and it has access to a large range of genetic resources

- It has a high technology stand available within the country. This is due to the enormous investments made in agricultural research, especially during the days of the Green Revolution, which created a strong scientific cadre, from scientist to technical assistants

- It has a large repertoire of skilled manpower which makes available comparative skills at half the cost

- Another advantage from the point of view of India is the cost of the technology itself. Biotechnology, unlike every other major technology to have developed in recent times, is not capital but labor intensive. This is a tailor made situation for a country strapped for cash but rich in manpower ${ }^{[22]}$

The protection of plant varieties and farmer's rights act, 2001: The history of the evolution of India's sui generis plant variety protection can be traced back to 1999 when The Plant Variety Bill was introduced in December 1999 with a view to start parliamentary process before the TRIPS implementation deadline of 1 st January $2000^{[23]}$. This draft was not at all comprehensive and was on the whole largely a plant breeder's rights legislation. In the event, the act was not adopted immediately but was referred to a joint parliamentary committee. After a number of hearings in 2000, the committee ended up substantially rewriting the bill. It maintained the main provision with respect to a plant breeder's rights regime but added an important new chapter on 'Farmer's Rights' ${ }^{, 24]}$. Thus the Committee in essence added an element to the first draft, which as analyzed below, has created certain imbalances in the overall legal regime proposed under the Plant Variety Act. 
The Plant Variety Act was finally passed in 2001. Following the adoption of the Act, rules were framed in $2003^{[25]}$. The Plant Variety Act of 2001 has a clear twin mandate. It is premised on the need 'to recognize and protect the rights of farmers in respect of their contributions made at any time in conserving, improving and making available plant genetic resources for the development of new plant varieties' as well as 'to protect plant breeder's rights to stimulate investment for research and development, both in public and private sector for the development of new plant varieties ${ }^{, 26]}$. In general the aims of the act are much broader in scope than those of the UPOV Convention.

Positive features of the act: Under the plant variety act, the new plant variety must conform to the criteria of novelty, distinctiveness, uniformity and stability. It is remarkable that the PPVFR allows four types of varieties to be protected: a new variety, an extant, an essentially derived and a farmers' variety ${ }^{[27]}$. Extant variety is a broad category covering varieties available in India that are notified under Section 5 of the Seeds Act 1966 in situations where it has been deemed necessary to regulate the quality of seeds for specific variety sold for use in agriculture. Farmer's varieties are those about which there is common knowledge or which are in the public domain. An essentially derived variety is one that can be distinguished from the initial variety but retains its essential characteristics. This multiple rights system aims to distribute benefits equitably.

The PPVFR gives different protection durations for different cases. More precisely, for trees and vines, the period of protection is 18 years from the date of registration of the variety; for extant varieties, the period of protection is 15 years from the date of the notification of that variety by the Central Government under Section 5 of the Seed Act 1996 and for other varieties, the period of protection is 15 years from the date of registration of the variety.

The main contribution of the Act is the possibility granted under Section 39 to farmers to be offered exactly the same rights as commercial breeders for their varieties. In other words, farmers have the right to save, use, sow, re-sow, exchange, share, or sell their farm produce, including seeds. The only proviso is that these seeds must not be 'branded' with breeder's registered name. In this way both farmers and breeders rights are protected. The breeder is rewarded for his innovation, but without being able to threaten the farmer's ability independently to engage in his livelihood and supporting the livelihood of other farmers ${ }^{[28]}$. In addition, as a part of the farmers' rights, compensation can be claimed if a variety fails to provide the expected performance under given condition and leads to crop failure.

Some other valuable features of the act include are the explicit and detailed disclosure requirements in the passport data required at the time of applying for a breeder's certificate; the complete ban on Gene Use Restricting Technology (GURT) that is terminator technology, exemption of fees for farmers and the protection guaranteed against innocent infringement.

With specific respect to the environment, the Act recognises that farmers are not only innovators but also important conservers of agro biodiversity. Thus where farmers contribute to the conservation of genetic resources of land races and wild relatives of plants whose genes have been used in varieties protected under the Act or where they contribute to the improvement of these same plants through selection and preservation, they are entitled to a financial reward. This reward will be instituted by the National Gene Fund set up under the Act. The conservation focus even though narrowed for economic use alone, is noteworthy for atleast acknowledging the link between conservation and use.

Inadequacies in the act: Despite being christened as a progressive legislation in the field of PVPs, the Plant variety act faces a number of shortcomings. To begin with, it remains unclear whether farmers will ever be able to benefit from the relatively generous provisions of the act. while there exists a framework in place for the registration of farmer's varieties, very few farmers if any will be able to benefit from its provisions because their varieties generally do not meet the criteria of distinctiveness, uniformity and stability- a criteria directly picked up from the UPOV Convention designed exclusively for commercial breeders.

The second corollary is with regard to the essentially derived varieties. On the one hand, the Act indicates clearly that it seeks to provide a framework for the protection of the rights of commercial breeders as well as farmers. On the other hand while India is officially seeking to join the 1978 Act of the UPOV Convention, the Act provides for not only the protection of new varieties but also for the protection of essentially derived varieties.

Further, under Section 46.2 (d), the use of farmer's varieties to breed new varieties will have to be paid for and the revenue will flow into a Gene Fund. Despite the good intentions of protecting the farming community, the formulation of this section is likely to create problems in implementation because the drafting is poor, even incomplete. With respect to the liability 
clause for protection against bad seed, too much discretion is left to the plant variety authority which will fix the compensation. According to national NGOs working in the field such as Gene Campaign, this will lead to arbitrary decisions. They suggest that if it is proved that a breeder has made false claims and that as a result the farmer has suffered a crop failure, compensation of at least twice the projected harvest value must be awarded. In addition a jail term should be provided if the offence is repeated. Thus it can be concluded that the Act exhibits noble intentions in principle but in practice, it seems likely that the original emphasis of the 1999 Bill is likely to prevail.

An evaluation: At the very outset, the Plant Variety Act is not the only legislative instrument of relevance in India in the field of plant variety protection. There are at least two other Acts which are related. Striking a balance between economic use and conservation will be difficult to achieve without specific coordination between these Acts at the implementation level. The first is the Patents Act 1970. There is in principle a clear distinction between the two since the Patents Act specifically prohibits the patentability of plant varieties. Given that patents will in the future be sought on biological material used for inventions in the field of agricultural genetic engineering, there is a direct link with agriculture. There is also a direct link with farmer's varieties and extant varieties. These links are not mentioned in the Act. The second related act is the Biodiversity Act 2002 which in practice focuses mainly on access to biological resources, control over these resources and related knowledge and benefit sharing. Further, the Biodiversity Act specifically delves into IPR related issues; therefore the potential for confrontation in practice is significant.

Thus there exist substantive overlaps between the mandates of the three Acts which require specific provisions for their coordination. Also, the question of benefit sharing is likely to cause significant problems once the three Acts are implemented. For example the Patents Act does not provide for any benefit sharing even though benefit sharing in cases where patents related to biological material are granted is provided for under the Biodiversity Act. Further, new international legal obligations have come into force since the Act was adopted such as the PGRFA Treaty which must be integrated harmoniously.

It can this be concluded that the 'Indian sui generis' regime can be viewed from two absolutely varying perspectives. On one hand, the Plant Variety Act is a progressive legislation as it provides a clear acknowledgement that farmer's rights can be conceived as intellectual property rights, in exactly the same way as other products of human creativity. On the other hand, it appears likely that the chapter on farmer's rights will not be implemented owing to its incoherent construction, lack of coordination with other Acts added with the Governmental pressure, upon joining the opposing UPOV Convention.

\section{CONCLUSION}

Today's international legal framework remains partly inconclusive with regard to the type of agricultural management that it seeks to encourage. While the TRIPS Agreement generally seeks to foster private appropriation of inventions, the PGRFA Treaty is much more hesitant since it endeavors to foster free flows of plant genetic resources while accepting the validity of intellectual property rights claims over transformed material. This confirms that there is no a priori reason to emphasize the strengthening of IPR protections rather than its weakening. Perhaps due to the decentralized nature of international law, several treaties with the same mandates find no coordination mechanisms in their provisions. The TRIPS Agreement and the biodiversity convention are in a relation of equality in so far as each has been negotiated independently by member states and carries the same weight in legal terms. The TRIPS Agreement makes absolutely no mention of any environmental treaty and does not even acknowledge the possibility of any overlaps. The Biodiversity Convention includes a general provision on IPR but provides no mechanism in case of a contradiction.

In the light of such a fragmented position of international law it is important to conclude that IPR in agriculture and sustainable development are indeed integrated. The introduction of intellectual property rights in agriculture cannot be dissociated from the conservation of agro biodiversity, the protection of traditional knowledge in general and the scope of life patenting which influences the development of genetic engineering. The fine balance between the complex aspirations and vulnerabilities of the present times lies in sound international decisions. Thus harmonizing the splintered international law is the only solution to the mutual needs of the north and the south

An alternate treaty such as the one drafted by gene campaign along with centre for environmental and agricultural development called the Convention of Farmers and Breeders $(\mathrm{CoFaB})^{[29]}$ can be one suggested solution to the dilemma of the developing nations. CoFab provides an alternative treaty to UPOV to provide a forum for developing world to implement 
their farmers and breeders rights. It reflects their strengths and vulnerabilities and seeks to secure their interests in agriculture policy making ${ }^{[28]}$.

Finally, speaking of overlaps, the final word with regard to plant variety protection lies in another inter related yet crucial matter, that of 'agricultural subsidies'. It is submitted that introducing PVPs will not affect international trade in agriculture positively so long as agricultural subsidies limit access to the markets. Developing nations' ability to benefit from PVPs depends on interaction with other market mechanisms. Therefore, in order for nations to benefit from PVPs, the impediments from agricultural subsidies must be removed first.

\section{REFERENCES}

1. Kameri-Mbote, A.P., 1999. Commission on Genetic Resources for Food and Agriculture, Possible Formulas for the Sharing of Benefits Based on Different Benefit-Indicators. 8th Edn., Rome, pp: 19-23.

2. Shiva, V., 1994. Farmers Rights and the Convention of Biological Diversity. In: Biodiplomacy-Genetic Resources and International Relations. Sanchez, V. and C. Juma (Eds.). African Centre for Technology Studies, Nairobi, Kenya, pp: 107.

3. Rangnekar, D., 2000. Intellectual Property Rights and Agriculture: An Analysis of the Economic Impact of Plant Breeder's Rights. Landon, Actionaid UK., pp: 58.

4. Kameri-Mbote, P., 1994. Agreement on Trade Related Aspects of Intellectual Property Rights, Marrakech. Intl. Leg. Mat., 33: 1125.

5. Esquinas-Alcazar, J., 1996. The Relation of Farmer's Rights. In: Agribiodiversity and Farmer's Rights 2, Swaminathan, M.S. (Ed.). New Delhi, Konark.

6. Ragavan, S., 2005. To sow or not to sow: Dilemmas in creating new rights in food. University of Oklahoma. http://papers.ssrn.com/sol3/papers.cfm?abstract_id $=791666$

7. Verkey, E., 2007. Law of Plant Varieties Protection. Allahabad, Eastern Book Company, ISBN: 8170129621, pp: 13.

8. Chaturvedi, S., 2002. Agricultural genetic engineering and new trends in intellectual property rights regime-challenges before developing countries. Econ. Political Weekly, 37: 1212.

9. Cullet, P., I2005. Intellectual Property Protection and Sustainable Development. LexisNexis Butterworths, Delhi, ISBN: 81-8038-140-8, pp: 202-203.
10. Barton, J.H., 2003. Nutrition and Technology Transfer Policies. UNCTAD/ICTSD Draft Paper, Geneva.

11. Mitra, S., 2008. Patent and food security-opening Pandora's box. J. Intel. Property Rights, 13: 145-151.

12. Kocchar, S., 2008. Institutions and capacity building for the evolution of intellectual property rights regime $\mathrm{v}$-analysis of review of trips agreement and $\mathrm{r}$ and $\mathrm{d}$ prospect in Indian agriculture under IPR regime. J. Intel. Property Rights, 13: 536-547.

13. FAO, 2003. World Agriculture-Towards 2015/2030 Earthscan, London, pp: 246.

14. Kuyek, D., 2001. Intellectual property rights: ultimate control over $\mathrm{R}$ and $\mathrm{D}$ in Asia. http://www.grain.org/publications/reports/asiaipr.htm

15. United State Patent and Trademark Office, 1994. Agreement on trade related aspects of intellectual property rights, Marrakech. http://www.uspto.gov/web/offices/com/doc/urugua $\mathrm{y} /$ finalact.html

16. FAO, 1989. Resolution 4/89, agreed interpretation of the international undertaking. Proceeding of the Conference of the FAO, 25th Session, Nov. 11-29, Doc C89/REP, Rome.

17. SIPO, 2001. International Treaty on plant genetic http://www.sipo.gov.cn/sipo2008/ztzl/ywzt/yczyhct zsbh/zlk/gjgy/200804/P020080411461274286262. pdf

18. UPOV, 1961.International convention for the protection of new varieties of plants. Paris. http://www.jpo.go.jp/shiryou_e/s_sonota_e/fips_e/ pdf/treaty_e/upov_e/e_new_varieties_of_plants.pdf

19. Pegu, R., 2002. Will India's proposed membership of UPOV jeopardize farmers' rights: An interview with Dr. Suman Sahai. http://www.kisanwatch.org/eng/features/dec02/fea 12_suman_sahai.htm

20. Kumar, A., 2008. Towards patentability of essentially biological processes. J. Intel. Property Rights, 13: 129-138.

21. Singh, H., 2007. Plant variety protection and food security: Lessons for developing countries. J. Intel. Property Rights, 12: 391-399.

22. Sahai, S., 1999. Intellectual Property Rights and Community Rights, Bioresources and Biotechnology: Policy Concerns for the Asian Region, Gene Campaign, New Delhi, pp: 124-25.

23. Brahmi, P., S. Saxena and B.S. Dhillon, 2004. Protection of plant varieties and farmer's rights act of India. Curr. Sci., 86: 392-398. http://www.ias.ac.in/currsci/feb102004/392.pdf 
24. Lok Sabha Secretariat, 2000. Joint Committee on the Protection of Plant Varieties and Farmer's Rights Bill 1999. Report of the Joint Committee. http://openlibrary.org/books/OL3975683M/Joint_C ommittee_on_the_Protection_of_Plant_Varieties_a nd_Farmers'_Rights_Bill_1999

25. NIC, 2003. Protection of plant varieties and farmer's rights rules. http://dacnet.nic.in/seednet/seeds/Material/Farmers _Right_Rule_2003/index.pdf

26. Hereinafter Plant Variety Act, 2001. Protection of plant varieties and farmer's rights act 53 of 2001. http://www.grain.org/brl_files/india-pvp-2001-

en.pdf
27. Liu, W. and L. Gu, 2008. Intellectual property protection of plant varieties in Asian developing countries. Biotechnol. Law Rep., 27: 529. DOI: 10.1089/blr.2008.9903

28. Sahai, S., 2002. India's Plant Variety Protection and Farmer's Rights Legislation. In: Global Intellectual Property Rights: Knowledge, Access and Development, Drahos, P. and R. Mayne (Eds.). Palgrave Macmillan, pp: 222.

29. UNDP, 1999. Human Development Report 1999. http://hdr.undp.org/en/media/HDR_1999_EN.pdf 